\title{
ANALISIS KESALAHAN PENGGUNAAN PENGGUNAAN KALIMAT EFEKTIF DAN TANDA BACA PADA TEKS EKSPLANASI SISWA KELAS VIII SMP NEGERI 1 LABUHAN DELI TAHUNPEMBELAJARAN 2016/2017
}

\author{
Oleh \\ Juni Kristian Sagala
}

\begin{abstract}
Penelitian ini bertujuan untukmendeskripsikan dan mengklasifikasikan bentuk kesalahan penggunaan kalimat efektif dan tanda baca yang terdapat pada teks eksplanasi siswa kelas VIII SMP Negeri 1 Labuhan Deli tahun pembelajaran 2016/2017, mendeskripsikan apa saja bentuk kesalahan yang paling dominan yang ditemukan dalam teks eksplanasi siswa kelas VIII SMP Negeri 1 Labuhan Deli. Penelitian ini menggunakan pendekatan deskriptif kualitatif. Sumber data berasal dari dokumen berupa karangansiswa dan narasumber (informan) yang terdiri dari guru bahasaIndonesia serta siswa kelas VIII SMP Negeri 1 Labuhan Deli.Penelitian dilaksanakan dalam tiga tahap meliputi tahap prapenelitian, pelaksanaan penelitian, dan penyusunan laporan penelitian.Simpulan penelitian ini adalah sebagai berikut. Pertama, bentuk kesalahan penggunaan kalimat efektif yang terdapat dalam teks eksplanasi siswa terdapat lima aspek, yaitu kesalahan pada penggunaan kalimat yang tidak koherensi.,kesatuan, ketepatan, kehematan, dan kelogisan. Frekuensi kesalahan pada tataran koherensi adalah sebesar 47,5\%, kesalahan pada tataran kesatuan sebesar 22,85\%, kesalahan pada tataran ketepatan sebesar 7,5\%, kesalahan pada tataran kehematan sebesar 16,78\% dan kesalahan pada tataran kelogisan sebesar 5,35\%. Kedua,bentuk kesalahan penggunaan tanda baca yang terdapat dalam teks eksplanasi siswa terdapat dua aspek, yaitu kesalahan pada penggunaan tanda titik dan tanda koma . Frekuensi kesalahan pada penggunaan tanda titik adalah sebesar 55,65\% dan frekunsi kesalahan pada penggunaan tanda koma adalah sebesar $44,34 \%$. Ketiga kesalahan penggunaan kalimat efektif yang paling dominan ditemukan pada teks ekplanasi siswa kelas VIII SMP Negeri 1 Labuhan Deli adalah kesalahan penggunaan ketidakhorensian dengan frekuensi sebesar 47,5\%.Keempat kesalahan penggunaan tanda baca yang paling dominan ditemukan pada teks ekplanasi siswa kelas VIII SMP Negeri 1 Labuhan Deli adalah kesalahan penggunaan tanda baca yaitu tanda titik dengan frekuensi sebesar 55,65\%.
\end{abstract}

Kata kunci: analisis kesalahan, teks eksplanasi, penggunaan kalimat efektif dan tanda baca.

\section{PENDAHULUAN}

Bahasa berperan penting dalam kehidupan sehari-hari karena setiap kegiatan manusia menggunakan bahasa. Melalui bahasa seseorang mampu berbahasa dengan orang lain. Melalui bahasa mampu manusia mampu mengungkapkan ide, atau gagasan seperti persaan sedih, senang, dan amarah.sebagai alat berintregrasi dan beradaptasi sosial dan sebagai kontrol sosial. Pada 
hakikatnya fungsi utama bahasa adalah alat komunikasi.Kegiatan berbahasa dalam kehidupan sehari-hari terlihat dalam empat aspek keterampilan berbahasa.

Satu dari empat keterampilan berbahasa, yakni; keterampilan menulis. Menulis merupakan suatu keterampilan berbahasa yang digunakan untuk berkomunikasi secara tidak langsung, tidak melalui tatap muka dengan orang lain. Menulis merupakan sarana komunikasi antara penulis dan pembaca secara tidak langsung, karena kegiatan menulis dapat mencurahkan gagasan, pendapat dan perasaan ke dalam bentuk tulisan (Tarigan,1994:3). Salah satu keterampilan menulis yang dipelajari dalam mata pelajaran Bahasa Indonesia adalah menulis teks eksplanasi di samping jenis teks-teks yang lainnya (narasi, deskripsi, argumentasi, persuasi, eksemplum,eksposisi dan sebagainya).

Teks eksplanasi adalah sebuah teks yang berisi tentang proses-proses yang berhubungan dengan fenomena-fenomena alam, sosial, ilmu pengetahuan, budaya, dan lainnya.Teks ini disusun dengan struktur yang terdiri atas bagian-bagian yang memperlihatkan pernyataan umum (pembukaan), deretan penjelasan (isi), dan interpretasi/penutup. Bagian pernyataan umum berisi informasi singkat tentang apa yang dibicarakan. Bagian deretan penjelas berisi urutan uraian atau penjelasan tentang peristiwa yang terjadi.Sementara itu, bagian interpretasi berisi pendapat singkat penulis tentang peristiwa yang terjadi.Bagian ini merupakan penutup teks eksplanasi yang boleh ada atau tidak ada. (Mahsun, 2013: 49).

Dalam teks eksplanasi hendaknya penulis (siswa) mampu menuangkan gagasannya secara sistematis, runtut, dan lengkap. Namun kenyataannya, masih banyak persoalan yang dihadapi siswa SMP N 1 Labuhan Deli kelas VIII dalam menulis teks eksplanasi. Terlihat masih banyak siswa yang mendapat nilai di bawah standar penilaian yaitu 75. Dari hasil wawancara yang dilakukan kepada salah satu guru bahasa Indonesia ibu Elliati S.Pd masalahmasalah yang dihadapi siswa dalam menulis teks eksplanasi antara lain : (1) sulit menentukan tema; (2) keterbatasan informasi yang disebabkan kurangnya referensi; (3) adanya rasa malas atau bosan; dan (4) penguasaan kaidah bahasa yang kurang baik. Sehingga banyak kesalahan berbahasa yang dilakukan siswa dalam menulis teks eksplanasi.

Mengingat banyaknya aspek yang dapat diteliti dalam kegiatan analisis kesalahan berbahasa, maka tidak semua aspek digunakan oleh peneliti dalam penelitian ini. Berdasarkan pengalaman peneliti saat melaksanakan Program Pengalaman Terpadu (PPLT) di SMP Negeri 1 Labuhan Deli Tahun Pembelajaran 2016/2017 dalam menulis sebuah karangan banyak 
kesalahan berbahasa yang dilakukan siswa dalam bidang ejaan, diksi, dan kalimat. Hal ini juga relevan dengan penelitian yang telah dilakukan oleh Sumarwati (2010) Analisis Kesalahan Berbahasa dalam Karangan Eksposisi Siswa Sekolah Menengah yang menemukan bahwa pada umumnya organisasi tulisan dalam karangan siswa masih menampakkan penalaran bahasa yang kurang logis, dan terdapat banyak kesalahan bahasa yang meliputi pemakaian ejaan, diksi, kalimat, dan ada beberapa tulisan yang sama atau mirip.

Berdasarkan latar belakang di atas mendorong peneliti untuk meneliti kesalahan berbahasa ditinjau dari beberapa aspek yaitu penggunaan kalimat efektif dan penggunaan tanda baca pada teks eksplanasi siswa kelas VIII SMP Negeri 1 Labuhan Deli.

\section{METODE PENELITIAN}

Metode penelitian adalah cara ilmiah untuk mendapatkan data dengan tujuan dan kegunaan tertentu atau suatu kegiatan yang secara sistematis, direncanakan oleh para peneliti untuk memecahkan permasalahan yang hidup dan berguna bagi masyarakat, maupun bagi peneliti itu sendiri (Sukardi 2003:17). Metode penelitian merupakan hal yang penting untuk diperhatikan dalam sebuah penelitian.Hal ini disebabkan segala kegiatan yang dilakukan dalam sebuah penelitian dalam upaya menemukan dan membuktikan sesuatu sepenuhnya tergantung pada metode yang digunakan.Penelitian ini menggunakan pendekatan kualitatif. Penelitian dengan pendekatan kualitatif yaitu penekananya tidak pada pengujian hipotesis melainkan pada

usaha menjawab pertanyaan penelitian melalui cara-cara berfikir formal dan argumentatif (Azwar, Saifuddin 2007:5) Pengumpulan data yang dihasilkan dari penelitian bukanlah angkaangka, tetapi berupa kata-kata atau gambaran sesuatu disebut penelitian deskriptif. Oleh karena itu, penelitian ini merupakan penelitian deskriptif kualitatif.

\section{HASIL PENELITIAN DAN PEMBAHASAN}

\section{A. Hasil penelitian}

1. Bentuk Kesalahan Penggunaan Kalimat Efektif pada Teks Eksplanasi Siswa Kelas VIII SMP Negeri 1 Labuhan Deli

Hasil penelitian ini berupa deskripsi kesalahan penggunaan kalimat efektif dan tanda baca pada teks eksplanasi siswa kelas VIII SMP Negeri 1 Labuhan Deli Tahun Pembelajaran 2016/2017. Seperti yang telah dibicarakan terdahulu data dalam penelitian ini berupa kesalahan 
penggunaan kalimat efektif dan tanda baca pada teks ekplanasi siswa kelas VIII SMP Negeri 1 Labuhan Deli 2016/2017 dan sumber data adalah teks eksplanasi siswa kelas VIII SMP Negeri 1 Labuhan Deli tahun pembelajaran 2016/2017. Kesalahan yang dilakukan siswa kelas VIII SMP Negeri 1 Labuhan Deli pada penggunaan kalimat efektif adalah adanya kesalahan ketidakkoherensian, ketepatan, kesatuan, kehematan, dan ketidaklogisan.

\section{Bentuk Kesalahan Penggunaan Tanda Baca pada Teks Eksplanasi Siswa Kelas VIII SMP Negeri 1 Labuhan Deli}

Dan dari hasil penelitian, kesalahan tanda baca yang dilakukan siswa ada dua yaitu tanda koma dan tanda titik.

\section{Kesalahan Penggunaan Kalimat Efektif yang Paling Dominan yang Ditemukan pada Teks Eksplanasi Siswa Kelas VIII SMP Negeri 1 Labuhan Deli}

Kesalahan penggunaan kalimat efektif yang paling dominan yang ditemukan pada teks eksplanasi siswa kelas VIII SMP Negeri 1 Labuhan Deli `adalah penggunaan kalimat yang tidak koherensi Frekuensi kesalahan sebesar 47,5\%, kesalahan pada tataran kesatuan sebesar 22,85\%,

kesalahan pada tataran ketepatan sebesar 7,5\%, kesalahan padatataran kehematan sebesar $16,78 \%$ dan kesalahan pada tataran kelogisan sebesar 5,35\%.

\section{Kesalahan Penggunaan Tanda Baca yang Paling Dominan yang Ditemukan pada} Teks Eksplanasi Siswa Kelas VIII SMP Negeri 1 Labuhan Deli

Dan Kesalahan penggunaan tanda baca yang paling dominan yang ditemukan pada teks eksplanasi siswa kelas VIII SMP Negeri 1 Labuhan Deli adalah penggunaan tanda titik . Frekuensi kesalahan adalah sebesar 55,65\% dan frekunsi kesalahan pada penggunaan tanda koma adalah sebesar $44,34 \%$.

\section{B. Pembahasan Penelitian}




\section{Bentuk Kesalahan Penggunaan Kalimat Efektif pada Teks Eksplanasi Siswa}

Kelas VIII SMP Negeri 1 Labuhan Deli

Dari hasil penelitian contoh kesalahan koherensi yang ditemukan,

(1) A11.Pr.2 KI.3, "Longsor dapat menewaskan banyak orang peristiwa. Itu terjadi jika curah hujan yang sangat tinggi lagi".

(2) A11.Pr.2 K1.4, "Seperti longsor yang ada dijawa. Banyak yang memakan korban, belasan rumah hancur, peralatan2 hancur".

(3) A1.Pr 3.K1.4, "Agar tidak terjadi longsor warga tidak menyumbat air dan karena hujan yang bertambah deras pula dan akan masuk kedalam tanah mulai basah lalutanah jatuh karena sudah tidak keras lagi".

Pada data (1) diatas terdapat kesalahan koherensi struktur kalimat tidak jelas atau rancu karena ada kata banyak orang peristiwa. Kalimat ini menjadi tidak rancu diperbaiki dengan kalimat,Jika curah hujan deras, maka longsor bisa mengakibatkan korban meninggal. Data (2) terdapat kesalahan salah dalam pemakaian kata dan frasa karenaada pemakaian kata banyak yang memakan korban, belasan rumah hancur. Kalimat ini menjadi efektif dapat diperbaiki dengan, Seperti longsor yang terjadi di Jawa, banyak korban yang meninggal, rumah, dan peralatan banyak hancur. Data (3) terdapat kesalahan salah dalam pemakaian kata dan frasa karena ada pemakaian kata deras puladan akan masuk kedalam tanah mulai basah lalutanah jatuh. Kalimat ini menjadi efektif dapat diperbaiki dengan, Agar tidak terjadi longsor, warga sebaiknya tidak menyumbat air. Karena jika air mengendap ditanah, maka hal ini yang menyebabkan tanah tidak kuat dan terjadi longsor.

Dari hasil penelitian contoh kesalahan kesatuan yang ditemukan,

(1) A12. Pr.1.K1.2,"Adalah gunung meletus meskipun memiliki tanda-tanda sebelum meletus, namun gunung berapi yang masih aktif tetap diwaspadai".

(2) A12. Pr.2.K1,"Gunung berapi memilki empat bagian yang memiliki peran berbeda saat meletusnya gunung tersebut keempat bagian tersebut adalah struktur bawah yang berbeda gunung rekahan bisa mencapai kedalam ribuan meter di awali dengan adanya peningkatan suhu kebawah dan getaran gempa vulkanik.

(3) A31.Pr.1 K1.3,'Bukan karena hujan saja yang mengakibatkan banjir tetapi disesabkan karena banyaknya sampah yang ada diselokan".

(4) A35.Pr.1.K1.3,"Dan harus ada rasa peduli kita terhadap kebersihan karena merupakan salah satu menghindari dari bencana lam salah satunya adalah kebanjiran". 
Pada data (1) diatas terdapat kesalahan memakai kata depan yang salah sehingga gagasan kalimat menjadi kacau yaitu penggunaan kata adalah kalimat inimenjadi kalimat yang jelas kesatuanya dapat diperbaiki dengan kalimat, Gunung yang akan meletus memiliki tandatanda, dan gunung berapi yang masih aktif tetap diwaspadai. Data (2) tidak jelas apa maksud penulis karena tidak dijelaskan keempat bagian gunung tersebut. Kalimat menjadi jelas kesatuanya dapat diperbaiki dengan kalimat, Gunung berapi memilki empat bagian yang memiliki peran berbeda saat meletus.Keempat bagian tersebut keempat bagaian tersebut yaitu, (bagian ini terletak dibagian puncak gunung), kaldera (bagian gunung yang berbentuk seperti kawah), rekanan dan graben (bagian dari badan gunung, rekanan bisa mencapai kedalaman ribuan meter) dan depresi vulkano. Data (3) terdapat kesalahan memakai kata depan yang salah sehingga gagasan kalimat menjadi kacau yaitu kata bukankalimat inimenjadi kalimat yang jelas kesatuanya dapat diperbaiki dengan kalimat.Banjir disebabkan karena tersumbatnya sampah ketika hujan turun. Data (4) terdapat kesalahan memakai kata depan yang salah sehingga gagasan kalimat menjadi kacau yaitu kata Dankalimat inimenjadi kalimat yang jelas kesatuanya dapat diperbaiki dengan kalimat, Kita harus peduli terhadap kebersihan, karena kebersihan adalah upaya untuk menghindari banjir.

Dari hasil penelitian contoh kesalahan ketidakepatan yang ditemukan,

(1) A2.Pr.1.K1.2, "Yang termasuk tsunami yaitu, Air Danau yang membesar atau yang mengalir sangat kencang".

(2) A2.Pr.2.K1.2,"Karena longsor dapat banyak warga yang mengungsi agar tak ada longsor susulan"

Pada data (1) diatas terdapat kesalahan ketidaktepatan penggunaan konjungsi sehingga kalimat mejadi tidak tepat yaitu kata atau. Kalimat diatas menjadi tepat diperbaiki dengan kalimat, Tsunami yaitu gelombang air yang besar dan mengalir dengan cepat.Data (2) terdapat kesalahan ketidaktepatan penggunaan konjungsi sehingga kalimat mejadi tidak tepat yaitu kata agar tak ada.Kalimat diatas menjadi tepat diperbaiki dengan kalimat, karena longsor, masyarakat harus mengungsi ketempat yang lebih aman.

Dari hasil penelitian contoh kesalahan ketidakhematan yang ditemukan, 
(1) A11.Pr.1 K1.3, "Terjadi Tsunami terjadi banjir terlebih dahulu"

(2) A11.Pr.3.K1.2, "Akibat longsor ini tanah yang dulunya bagus sekarang sudah hancur dan para anak-anak tinggal dipengungsian".

(3) A31.Pr.1 K1.5 "Kalau terkena kebanjiran anak-anak tidak bisa sekolah Karena sekolahnya terkena kebanjiran anak-anak tidak bisa sekolah karena sekolahnya terkena kebanjiran. anak-anak kalau terkena kebanjiran anak-anak mau kesekolah memakai perahu".

Pada data (1) diatas terdapat kesalahan ketidakhematan terjadi karena pemakaian kata yang beulang yaitu kata terjadikalimat dapat dperbaiki dengan kalimat Terjadi banjir sebelum tsunami. Data (2) kesalahan terjadi karena pemakain kata mubajir yaitukata para anak-anak. Kalimat tidak mubajir dapat diperbaiki dengan kalimat, Akibat longsor, tanah dulunya bagus sekarang sudah hancur dan anak-anak harus tinggal dipengungsian.Data (3) kesalahan terjadi karena pemakaian kata yang berulang-ulang yaitu kata terkena kebanjirankalimat dapat dperbaiki dengan kalimat Akibat banjir, anak-anak sekolah menjadi terhalang untuk bersekolah.

Dari hasil penelitian contoh kesalahan ketidaklogisan yang ditemukan,

(1) A12. Pr.4. K5 "Dan lava gunung meletus akan berjalan kerumah. Rumah warga lava ini keluar dari perut bumi dan ada batu-batu yang terkena ada guncangan gunung maka batu-batu bara akan keluar dari gunung tersebut".

(2) A31.Pr.1.K1.2, "Supaya tidak terkena kebanjiran, semua orang terkena kebanjiran". Dalam karangan siswa

(3) A35.P2.K1.3," Karena penyakit berdarah disebabkan karena adanya sampahsampah yang tergenang karena air genangan air yang mengakibatkan bibit-bibit nyamuk datang dan juga penyakit lainya".

Pada data (1) diatas terdapat kesalahan ketidaklogisan karena seolah-olah rumah warga yang mengeluarkan lava. Kalimat tersebut logis diperbaiki dengan kalimat, Akibat guncangan gunung, batu-batu dan lava keluar dari gunung tersebut. Data (2) kesalahan terjadi tidak masuk akal apa maksud penulis Warga harus menjaga kebersihan lingkungan agar, tidak terjadi banjir.Data (3) kesalahan terjadi karena seolah-olah didalam air ada genangan air.Kalimat tersebut logis diperbaiki dengan kalimat, Penyakit berdarah dan penyakit lainya disebabkan karena sampah-sampah dan genangan air.

Dan kesalahan yang sering dilakukan siswa adalah tanda titik, siswa seringtidak menggunakan tanda titik diakhir kalimat yang bukan pertanyaan atau seruan. Hal tersebut dijadikan sebagai suatu kesalahan dalam penggunaan tanda baca karena tidak sesuai dengan kaidah penggunaan tanda baca dalam Putrayasa, Ida Bagus (2007:30). 
Dari analisis penggunaan tanda baca, Kesalahan-kesalahan tanda koma yang sering dilakukan siswa adalahsiswa tidak memenuhi aturan tanda koma dipakai dibelakang kata atau ungkapan penghubung, tidak memenuhi aturan tanda koma yaitu tanda koma dipakai diantara unsur-unsur suatu pemerincian, tanda koma dipakai untuk memisahkan anak kalimat dari induk kalimat apabila kalimat tersebut mendahului induk kalimatnya, dan tanda koma dipakai untuk memisahkan kalimat setara yang satu dari kalimat setara berikutnya.Hal tersebut dijadikan sebagai suatu kesalahan dalam penggunaan tanda baca karena tidak sesuai dengan kaidah penggunaan tanda baca. Kesalahan penggunaan tanda koma yang ditemukan adalah sebanyak 149 kesalahan yang paling sedikit dari kesalahan penggunaan tanda titik.

Kesalahan penggunaan kalimat efektif dan tanda baca sering dilakukan siswa karena Kurangnya latihan menulis. Untuk itu, siswa perlu diberikan motivasi agar tergugah untuk membuat tulisan. Dari hasil penelitian, diketahui bahwa pembelajaran menulis di SMP tersebut belum sepenuhnya diterapkan dengan pendekatan proses. Karena dalam menulis sebuah teks siswa masih memiliki masalah yang sangat serius termasuk dalam penguasaan kaidah bahasa dan keefektifan bahasanya. Tidak adanya kontrol yang kuat dalam proses menulis membuat kesalahan berbahasa tersebut terjadi secara berkelanjutan. Sebagai suatu keterampilan yang produktif dan ekspresif, keterampilan menulis tentu tidak mudahdikuasai oleh seseorang begitu saja.

Oleh karena itu, jika seseorang ingin dapat memiliki ketrampilan menulis yang baik, maka ia harus melewati tahap-tahap atau proses menulis untuk menghasilkan tulisan yang baik dan benar. Dengan mengikuti tahapan-tahapan yang semestinya dilakukan, siswa akan belajar dan memperoleh pengalaman bagaimana proses menulis yang benar. Tentu saja adanya kesalahan-kesalahan berbahasa dalam teks yang dibuat oleh siswa tersebut dapat dikurangi karena sebelum tahap akhir penulisan, siswa terlebih dahulu melakukan tahap revisi dan pengeditan.Jadi, hasil karangan final siswa adalah teks yang sudah mengalami tahap perbaikan sebaik-baiknya bukan berupa teks sementara lagi.

\section{PENUTUP}

Berdasarkan hasil penelitian ini dapat disimpulkan bahwa bentuk kesalahan Penggunaan kalimat efektif terdapat 5 bentuk dan kesalahan tanda baca ada dua pada teks eksplanasi siswa kelas VIII SMP Negeri 1 Labuhan Deli tahun pembelajaran 2016/2017 kelima bentuk penggunaan kalimat efektif yaitu kesalahan pada penggunaan kalimat yang tidak koherensi, 
kesatuan, ketepatan, kehematan, dan kelogisan. Dan bentuk kesalahanan tanda baca yaitu kesalahan pada penggunaan tanda titik dan tanda koma.Kesalahan penggunaan kalimat efektif yang paling dominan yang ditemukan dalam teks eksplanasi siswa kelas VIII SMP Negeri 1 Labuhan Deli yaitu kesalahan penggunaan koherensi dengan frekuensi sebesar 47,5\%. Dan kesalahan penggunaan tanda baca yang paling dominan yang ditemukan dalam teks eksplanasi siswa kelas VIII SMP Negeri 1 Labuhan Deli yaitu kesalahan penggunaan tanda titik dengan frekuensi $55,65 \%$.

\section{DAFTAR PUSTAKA}

Azwar, Saifuddin. 2007. Metode Penelitian. Yogyakarta : Pustaka Pelajar.

Finoza,Lamuddin. 2010. Komposisi Bahasa Indonesia. Jakarta: Diksi Insan Mulia.

Kosasih, E. 2009.Tata bahasa Indonesia. Bandung: CV Cipta Dea Pustaka.

Mahsun.2014. Teks Dalam Pembelajaran Bahasa Indonesia (Kurikulum 2013).Jakarta:

PT Raja Grafindo Persada.

Masnur, Muslich. 2010. Tata Bentuk Bahasa Indonesia. Jakarta: Bumi Aksara.

Putrayasa, Ida Bagus. 2007.Kalimat Efektif. Bandung:PT Refika Aditama.

Sukardi. 2003. Metodologi Penelitian Pendidikan. Yogyakarta: PT Bumi Aksara Sumarwati,dkk. Analisis Kesalahan Berbahasa Dalam Karangan Eksposisi Siswa Sekolah Menengah Atas. jurnal penelitian bahasa, Volume1, Nomor 1, Desember 2012.

Tarigan, Henry Guntur.1994. Menulis Sebagai Suatu Keterampilan Berbahasa Bandung: Penerbit Angkasa. 